\title{
THE INTERPLAY BETWEEN PROFESSIONAL IDENTITIES AND AGE, GENDER AND ETHNICITY
}

\section{INTRODUCTION ${ }^{1}$}

\author{
Dorien Van De Mieroop and Jonathan Clifton
}

The study of identity has become one of the most important foci of investigation in the social sciences. It has been discussed from many different angles and in many different fields, ranging from psychology to anthropology and from sociology to linguistics. Consequently, studies relating to issues of identity are extremely diverse and they are, as Bamberg et al. (2007: 1) note, a long way from providing a unified and harmonious field of study. Yet, despite this diversity, it has been observed that social constructionism provides a unifying thread that runs through current research on identity (De Fina et al. 2006: 2). From such a social constructionist perspective, and to paraphrase Hall (2000: 17), identities are never unified, rather they are fragmented, fractured and multiply constructed across different, often intersecting and antagonistic, discourses, practices and positions. Thus, instead of looking for a stable core of the self, identity should be viewed as indexical and occasioned (Antaki and Widdicombe 1998: 3 ) and research into identity should therefore focus on the way that it is locally and discursively constructed and how its fluidity is negotiated between interlocutors within a particular social practice. The process of the social construction of identity, thus, results in the construction of 'a number of contextual selves' (Wetherell and Maybin 1996: 223), which following Zimmerman (1998), exist both at proximal (i.e., turn-byturn orientation to sequences of talk) and distal (i.e., oriented-to extra-situational concerns achieved through sequences of talk) levels. Consequently, discursive identities, such as speaker and listener, which are contingent on the proximal turn-byturn context, reflexively make relevant to the interaction situated identities. These are related to specific settings (Zimmerman 1988: 426) and include, inter alia, such professional identities as teacher, manager, police officer. Furthermore, alignment between oriented-to discursive and situated identities is necessary for the participants to perform actions such as 'doing' a lesson, an emergency call, or business meeting. Zimmerman (1998: 90) adds a third level of analysis, that of transportable identities - or 'categorical' identities (Zimmerman 1992) - such as gender, age, ethnicity, which 'tag along' and can become interactionally relevant at any point in the interaction. It is

\footnotetext{
${ }^{1}$ The idea for this special issue originated from a panel on 'Identity in organizational settings' that was convened by Dorien Van De Mieroop and Jonathan Clifton during the 10th Convention of the Association for Business Communication (ABC) / 2nd Convention of Global Advances in Business Communication (GABC) in Antwerp, Belgium (27-29 May 2010). Some of the articles in this issue are based on a presentation during this panel.
} 
crucial however, to underline the importance of the modal can: Transportable identities should not be regarded as omnipresent, since they are often not oriented to and are thus often irrelevant for any given interaction. Furthermore, even if transportable identities are made relevant to the interaction, the result is not monolithic either, since 'we may act more or less middle-class, more or less female, and so on, depending on what we are doing and with whom' (Schiffrin 1996: 199). Of course, the same holds true for situated identities which are not continuously relevant in professional interaction either (Zimmerman and Boden 1991: 13). For example, side sequences may make relevant alternative identities and, even within the most formal setting, professional identities are constantly being negotiated. In sum, as Bucholtz (1999: 209) notes: 'Individuals engage in multiple identity practices simultaneously, and they are able to move from one identity to another.'

The collection of papers in this special issue is particularly concerned both with the way in which these transportable identities, and more specifically age, gender, and ethnicity, interact with situated professional identities and the interactional dynamics the interplay between these identity levels entails. The analyses in the articles in this issue all focus on the 'constant flux and interplay between different aspects of an individual's diverse social and personal identities in response to contextual influences' (Holmes 2006: 167) as this is talked into being on a turn-by-turn basis. This renders the study of identity quite a complex endeavour, especially since it is not only aimed at presenting a fine grained analysis of the data, but it also attempts to uncover the wider ideological consequences of such interaction. This is because at a proximal level identities-in-talk carry with them discursive rights and obligations which constrain allowable contributions to the interaction and thus affect what actions participants can accountably perform. Identities-in-use thus provide instances of social actors' commonsense understandings of identity as a resource for conducting their affairs which reflexively reproduces identity as an external and constraining social fact. As Deppermann (2007: 276) sums it up: 'identity categories and their associated actions, properties, and expectations concerning motives, aims, knowledge of category incumbents are tools for the organization and interpretation of experience' and they are thus essential to conceptions of social order. So this special issue aims to demonstrate the different ways in which the discursive analysis of the interplay between the identity levels constructs and negotiates power relations within their interactional context set against the backdrop of wider hegemonic concerns, societal norms, and expectations.

In particular, this special issue focuses on a specific type of situated identities, notably professional identities, which are identities that are constructed within, or which are related to, an institutional context (see also discussion of interview data below). Such a context 'sets limits around what [...] the institutional representative [...] can do during institutional discourse' (Agar 1985: 158; own italics). Again, the emphasis on the verb can in this quote refers to what the interlocutor is normatively expected to do in an institutional setting. This is because these contexts are not viewed as deterministic entities that rigidly define the interaction that takes place within them as 'institutional', but instead, 'interaction is institutional insofar as participants' institutional or professional identities are somehow made relevant to the work activities in which they are engaged' (Drew and Heritage 1992: 3-4). This emphasizes the central role of identity in the discursive construction of an 'institution' and the fact that both identity and the institution are discursive processes rather than essentialist entities. Yet despite this observation, one can still expect that in institutional settings particular professional 
identities are invoked, thus talking the institutional nature of the interaction into being. But even if/when professional identities become relevant to the interaction, they are not monolithic and they may have many different forms, ranging from individually focused expert identity constructions to the negotiation of collective institutional identities. Several different markers, such as the use of person reference, lexical choice (see e.g. Drew and Sorjonen 1997), hedges, directives and humour (see e.g. Holmes et al. 1999; Holmes and Stubbe 2003a), may contribute to these identity constructions. Moreover, since these ways of constructing identity always need to be studied within, and related to, their specific contexts, the way these identities, like other identities, are talked into being is manifold. However, professional identities are particularly interesting since they all share a similar tension between the individual and the collective, and are always in some way or another related to issues of power.

We aim to explore this link with power even further by focusing on the analysis of these professional identities in relation to issues of age, gender and ethnicity, which are all elements of a person's transportable identity that are prone to be in a tense relation with power in the workplace. Before going into this however, we first briefly introduce these issues, especially since prior research into these topics has been of varying degrees of intensity. On the one hand, and although the discursive construction of age is a typical element that is invoked in constructing novice/expert identities (cf Vasquez 2007), the topic of age has not yet attracted much attention in institutional interaction (though see the introduction by Coupland [2009] in a recent special issue of Ageing and Society). On the other hand, gender and ethnicity have certainly been the object of intensive study over the last few decades. Firstly, since Lakoff's (1973) influential study, many researchers have been inspired to investigate the particularities of women's ways of speaking and the relation between gendered interaction and power (see Eckert and McConnell-Ginet [2003: 1-6] for an overview). Recently, the essentialist perspective on identity inherent in much of this early work on gender and talk has evolved into a performatively oriented approach. Moreover, this has entailed a shift in focus to the local interactional level (see Holmes and Meyerhoff 2003: 8) which has resulted in a number of studies that, commensurate with the papers in this special issue, also assume a fine-grained analytical approach to professional identity in institutional contexts (see e.g. Wagner and Wodak 2006; Holmes and Stubbe 2003b; and Ostermann 2003). Secondly, globalization and migration has led to a multicultural society in which people are becoming more and more aware of their ethnic group membership. This has led not only to 'a problematization of the concept of identity itself' (De Fina 2006: 351) but also to a construction of 'unsettled' and 'challenged' selves (Baynham 2006: 376). Research into identity in institutional contexts has, naturally, also reflected this growing interest in ethnicity (e.g. Holmes et al. 2008; Gumperz 1982 [chapter 8]; Roberts 2011; and Schnurr et al. 2007).

In spite of the obvious differences between these three aspects of transportable identity (age, gender and ethnicity), there is an important similarity between the three in institutional settings: Women, people from ethnic minorities, and those with 'problematic' ages are disadvantaged since they are generally underrepresented in positions of power in the professions (Mullany 2010: 179). So in our current, globalized society, there is a clear relation between these aspects of transportable identity and the situated identities of the institutionally powerful, or, alternatively the powerless, and these power imbalances are reflected in the dominant societal discourses. In particular, those with transportable identities of age, gender or ethnicity that are disempowering 
may attempt to 'negotiate away' characteristics that are associated with these identities as they struggle for voice; and, as both Van De Mieroop and Angouri (this issue) point out, one way of resisting dominant discourses of age, ethnicity, or gender is to challenge the relevance of such transportable identities. As such, this special issue aims to bring together multiple views on the interplay between an individual's professional identity constructions and gender, age and/or ethnicity in the increasingly globalized workplace. All the contributions take a constructionist stance in focusing on how these different identities are talked into being and negotiated within their social and intercultural contexts, the latter being regarded as the 'creation of a new one [context]' rather than as 'the sum of two different contexts' (Verschueren 2008: 24).

Regarding these contexts, there is also some diversity in this issue: While some articles start from language as it occurs in the workplace (contributions by Ostermann and Comunello da Costa, and Reissner-Roubicek), others either complement these data with interviews (contributions by Angouri, and Schnurr and Zayts) or focus solely on interviews as data (Miglbauer and Van De Mieroop). The former two data types focus primarily on providing a direct insight into the local, turn-by-turn negotiation of identities as speakers construct them within the institutional context, while the latter data type (interviews) takes a step back from life and focuses on the 'lived and told' (Georgakopoulou 2006: 129) in a totally new context. Some debate has surrounded the pertinence of narratives and interviews to the study of identity. On the one hand, narratives and stories have been widely studied since they are generally regarded as 'a privileged locus for the negotiation of identities' (De Fina et al. 2006: 16). On the other hand, narratives have been criticized as a data source, and it has been argued that the contextually bound and fluid nature of identity becomes less pronounced, and in its place coherent and morally acceptable identities (Linde 1993) emerge that are more stable than identities in everyday interaction (see, for example, Georgakopoulou 2006 versus Freeman 2006). However, as the analyses in this special issue attest, it is essential to take a performative approach to such narrative data. Such an approach focuses on the way identities are constructed and negotiated with the interviewer as an 'active co-teller' (Ochs and Capps 2001: 23) in interviews that are regarded as coconstructed narratives in which meaning is jointly created (Holstein and Gubrium 2003). By highlighting the 'interactional dynamics of narrative emergence' (De Fina 2009: 254), De Fina argues that the criticism of the reflexive nature of interviews as data can be overcome. The contributions to this special issue also take such an interactional approach to narratives and as such, they contribute to the discussion around interview data, not as a resource, but as a topic (cf Rapley 2001: 304). Furthermore, by focusing on a common topic that is studied by means of different data sources, this special issue forms an interesting case for the comparison between (1) identities that are constructed on a turn-by-turn basis in the workplace and (2) identities that are taken out of their institutional contexts, transferred to a new interviewing context in which they are constructed through a process of reflexivity, and negotiated in interaction with the interviewer. These two different types of datasets complement one another and the combination of articles based either on naturally occurring data in the workplace or on interviews provides a synergy that adds to an emerging and multifaceted view of professional identity. Since each article represents a very particular angle on the topic, we conclude this introduction by giving a brief overview of each article's specific line of approach and perspective on identity in the workplace. In the first article, Ostermann and Comunello da Costa investigate interaction in three 
contrasting institutions set up to address the issue of domestic violence in Brazil (i.e., an all-female police station, and two crisis intervention centres: One run by feminist professionals and the other by lay-women from a working class community). More specifically, in order to analyze the relation between professional identity construction and gender, they look at preference organization when the people working in the different institutions assess the talk of their clients. Interestingly, the article challenges the essentialist, stereotypical, and ideologically-driven assumption that female professionals are inherently better equipped to deal with female complainants. Thus, the transportable identity 'woman' is demonstrated to be interactionally irrelevant as the situated identities of the professional dealing with complaints influence the interactional dynamics of the situation.

The second article in this collection, by Reissner-Roubicek, also uses transcripts of naturally-occurring talk - in this case, transcripts of gatekeeping interviews with female final year undergraduate engineering students just prior to their entry to the job market. Reissner-Roubicek considers the negotiation of the gendered identities of engineers that disadvantage and/or perpetuate the underrepresentation of women in the engineering profession. She thus tackles the issue of how the transportable identity 'woman' is made relevant to the negotiation of desirable characteristics associated with the professional identity of 'engineer'. Furthermore, in examining how professional identity is differentially constructed for female engineers and male engineers, she points to the hegemonic role of gendered identity construction in gatekeeping interviews and its equivocal relationship to discourses of equality, difference and diversity for a particular professional community.

The third article in this issue, by Angouri, uses both transcripts of meeting-talk and elicited ethnographic interviews from participants. The paper explores the discourse surrounding the phenomenon of the aging workforce and it problematises the way in which age is constructed and discusses how this is managed through the positioning of self and other. Angouri argues that, 'elderliness' or 'youngness' is not something people have or are, rather it is something that participants actively do as well as having it projected upon them in the process of identity negotiation. Consequently, Angouri demonstrates how age (as a transportable identity) can be made relevant to the interaction in order to subvert situated professional identities and so enact power based on age rather than professional status.

In the next article, which investigates the negotiation of professional identity in multicultural environments, Schnurr and Zayts also juxtapose interview data with transcripts of meeting-talk. In particular, they examine how expatriate professional identities as leaders are constructed and negotiated in ways that reflect the speakers' assumptions of the relevance of the host country's cultural expectations, values, and practices in relation to issues of power in leadership exchanges. Interestingly, they demonstrate that expatriate assumptions about cultural stereotypes are not necessarily talked into being when interacting with ethnic Chinese workers in Hong Kong.

The next two articles deal uniquely with interview data. Van De Mieroop considers the professional identity construction of three second generation immigrant women and analyses how the interviewees reject ethno-professional identities projected on them by the interviewer and how the relevance of ethno-gendered identities is replaced with professional identities that align with the western hegemonic model of work-life balance. Van De Mieroop argues that it is possible that this may be because the interviewees seek to align with societal norms which thus entails asserting their 
orientation to characteristics associated with their professional identities and downplaying ethno-gendered identities which are normatively irrelevant in an ideal workplace and in an ideal society. Finally, in a similar vein and using interview data from two professional women, Miglbauer looks at how the relevance of gender identities in the workplace can either be accepted or resisted. She links this to notions of power (Fairclough 2001) and indicates how the relevance of gender identities in the interviews invoke the hegemonic discourses of 'women should stay at home and look after the kids' and 'weapons are men's toys'. She concludes that these discourses can be resisted in talk by shifting from gendered to professional identities.

In conclusion, all these articles present quite diverse cases of how people construct - or deconstruct - the relevance of aspects of transportable identity in relation to their professional identities. This is achieved both as they go about their everyday workplace activities and when they take a step back from their professional activities and reflect on these in interaction with an interviewer, as such also negotiating the different levels of identity. In spite of the diversity in topics and angles, these articles all demonstrate the discursive volatility of identities and how this can be used to subvert hegemonic power relations and counter the dominant discourses of our present-day professional societies.

\section{References}

Agar, M. (1985) Institutional discourse. Text 5.3: 147-168.

Antaki, C., and S. Widdicombe (1998) Identity as an achievement and as a tool. In C. Antaki, and S. Widdicombe (eds.), Identities in Talk. London: Sage, pp.1-15.

Bamberg, M., A. De Fina, and D. Schiffrin (2007) Introduction to the volume. In M. Bamberg, A. De Fina, and D. Schiffrin (eds.), Selves and Identities in Narrative and Discourse. Amsterdam: John Benjamins Publishing Company, pp. 1-8.

Baynham, M. (2006) Performing self, narrative and community in Moroccan narratives of migration and settlement. In A. De Fina, D. Schiffrin, and M. Bamberg (eds.), Discourse and identity. Cambridge: Cambridge University Press, pp. 376-397.

Bucholtz, M. (1999) "Why be normal?": Language and identity practices in a community of nerd girls. Language in Society 28: 203-223.

Coupland, J. (2009) Discourse, identity and change in mid-to-late life: Interdisciplinary perspectives on language and ageing. Ageing \& Society 29.6: 849-861.

De Fina, A. (2006) Group identity, narrative and self-presentations. In A. De Fina, D. Schiffrin, and M. Bamberg (eds.), Discourse and identity. Cambridge: Cambridge University Press, pp. 351-375.

De Fina, A. (2009) Narratives in interview - The case of accounts; For an interactional approach to narrative genres. Narrative Inquiry 19.2: 233-258.

De Fina, A., D. Schiffrin, and M. Bamberg (2006) Introduction. In A. De Fina, D. Schiffrin, and M. Bamberg (eds.), Discourse and identity. Cambridge: Cambridge University Press, pp. 1-23. 
Deppermann, A. (2007) Using the other for oneself; Conversational practices of representing out-group members among adolescents. In M. Bamberg, A. De Fina, and D. Schiffrin (eds.), Selves and Identities in Narrative and Discourse. Amsterdam: John Benjamins Publishing Company, pp. 273-301.

Drew, P., and J. Heritage (1992) Analyzing talk at work: An introduction. In P. Drew and J. Heritage (eds.), Talk at work - Interaction in institutional settings (Studies in Interactional Sociolinguistics 8). Cambridge: Cambridge University Press, pp. 3-65.

Drew, P., and M.L. Sorjonen (1997) Institutional Dialogue. In T. Van Dijk (ed.), Discourse as social interaction. London: Sage, pp. 92-118.

Eckert, P., and S. McConnell-Ginet (2003) Language and Gender. Cambridge: Cambridge University Press.

Fairclough, N. (2001) Language and Power. 2nd ed. Harlow: Pearson.

Freeman, M. (2006) Life 'on holiday'? In defense of big stories. Narrative Inquiry 16.1: 131-138.

Georgakopoulou, A. (2006) Thinking big with small stories in narrative and identity analysis. Narrative Inquiry 16.1: 122-130.

Gumperz, J. (1982) Discourse strategies. Cambridge: Cambridge University Press.

Hall, S. (2000) Who needs 'identity'? In P. du Gay, J. Evans, and P. Redman (eds.), Identity: A Reader. London: Sage, pp. 15-30.

Holmes, J. (2006) Workplace narratives, professional identity and relational practice. In A. De Fina, D. Schiffrin, and M. Bamberg (eds.), Discourse and identity. Cambridge: Cambridge University Press, pp. $166-187$.

Holmes, J., M. Meredith, and S. Schnurr (2008) Impoliteness and ethnicity: Māori and Pākehā discourse in New Zealand workplaces. Journal of Politeness Research 4.2: 193-219.

Holmes, J., and M. Meyerhoff (2003) Different voices, different views: An introduction to current research in language and gender. In J. Holmes, and M. Meyerhoff (eds.), Handbook of Language and Gender. Oxford: Blackwell, pp. 1-17

Holmes, J., and M. Stubbe (2003a) Power and Politeness in the workplace. London: Longman.

Holmes, J., and M. Stubbe (2003b) 'Feminine' workplaces: Stereotypes and reality. J. Holmes, and M. Meyerhoff (eds.), Handbook of Language and Gender. Oxford: Blackwell, pp. 573-599.

Holmes, J., M. Stubbe, and B. Vine (1999) Constructing professional identity: "Doing power" in policy units. In S. Sarangi, and C. Roberts (eds.), Talk, work and institutional order; discourse in medical, mediation and management settings. Berlin/New York: Mouton de Gruyter, pp. 351-385.

Holstein, J.A., and J.F. Gubrium (2003) Active interviewing. In J.A. Holstein, and J.F. Gubrium (eds.), Postmodern interviewing. Thousand Oaks, CA: Sage, pp.67-80.

Lakoff, R.T. (1973) Language and woman's place. Language in Society 2.1: 45-79.

Linde, C. (1993) Life stories: The creation of coherence. Oxford: Oxford University Press.

Mullany, L.J. (2010) Gendered identities in the professional workplace: Negotiating the glass ceiling. In C. Llamas, and D. Watt (eds.), Language and Identities. Edinburgh: Edinburgh University Press, pp. 179191. 
Ochs, E., and L. Capps (2001) Living narrative, creating lives in everyday storytelling. Cambridge, MA: Harvard University Press.

Ostermann, A.C. (2003) Localizing power and solidarity: Pronoun alternation at an all-female police station and a feminist crisis intervention center in Brazil. Language in Society 32: 351-381.

Rapley, T.J. (2001) The art(fulness) of open-ended interviewing: Some considerations on analysing interviews. Qualitative Research 1.3: 303-323.

Roberts, C. (2011) 'Taking ownership': Language and ethnicity in the job interview. In K. Pelsmaekers, C. Rollo, T. van Hout, and P. Heynderickx (eds.), Displaying Competence in Organisations. Houndmills: Palgrave Macmillan, pp. 10-26.

Schiffrin, D. (1996) Narrative as self-portrait: Sociolinguistic constructions of identity. Language in Society 25: 167-203.

Schnurr, S., M. Meredith, and J. Holmes (2007) Being (im)polite in New Zealand workplaces: Māori and Pākehā leaders. Journal of Pragmatics 39: 712-729.

Vasquez, C. (2007) Moral stance in the workplace narratives of novices. Discourse Studies 9.5: 653-675.

Verschueren, J. (2008) Intercultural communication and the challenges of migration. Language and Intercultural Communication 8: 21-35.

Wagner, I., and R. Wodak (2006) Performing success: Identifying strategies of self- presentation in women's biographical narratives. Discourse \& Society 17.3: 385-411.

Wetherell, M., and J. Maybin (1996) The distributed self: A social constructionist perspective. In R. Stevens (ed.), Understanding the self. London: Sage, pp.219-279.

Zimmerman, D.H. (1988) On conversation: The conversation analytic perspective. In Communication Yearbook 11: published annually for the International Communication Association. Newbury Park: Sage, pp. 406-432.

Zimmerman, D.H. (1992) Achieving context, openings in emergency calls. In G. Watson, and R.M. Sieler (eds.), Text in Context, Contributions to Ethnomethodology. Newbury Park: Sage, pp. 35-51.

Zimmerman, D.H. (1998) Identity, context and interaction. In C. Antaki, and S. Widdicombe (eds.), Identities in talk. London: Sage, pp. 87-106.

Zimmerman, D.H., and D. Boden (1991) Structure-in-Action: An Introduction. In D. Boden, and D.H. Zimmerman (eds.), Talk and social structure: Studies in ethnomethodology and conversation analysis. Berkeley/Los Angeles: University of California Press, pp. 3- 21.

DORIEN VAN DE MIEROOP is an assistant professor of Dutch linguistics at the University of Leuven in Belgium. Her research focuses mainly on identity construction, both in institutional contexts (e.g. speeches, social work interactions, meetings) and in narratives and life stories. She has published a number of articles on this topic (including in Discourse \& Society, Discourse Studies, Journal of Pragmatics, Narrative Inquiry, Research on Language and Social Interaction, Pragmatics and Journal of Sociolinguistics).

Address: KU Leuven, Faculty of Arts, Blijde-Inkomststraat 21, P.O. Box 3308, B- 3000 Leuven, Belgium. E-mail: dorien.vandemieroop@arts.kuleuven.be 
JONATHAN CLIFTON has a Ph.D. in linguistics from Antwerp University and now works as a lecturer in the Department of Applied Linguistics at the University of Lille 3 in France. His research interests centre around the themes of workplace interaction and identities-in-talk.

Address: University of Lille 3, Faculty of Applied Linguistics, 14 Place Bodart Timal, F- BP 44759058

Roubaix, France. E-mail: jonathanclifton@hotmail.fr 